DR. W. H. FITTON'S MEMOIRS.

Sir,-Students interested in William Smith will remember a series of brilliant articles which appeared in The Edinburgh Review a century ago, dealing with Smith's maps, Buckland's Reliquice Diluvianæ, and other important geological publications. These were anonymous, but by some were attributed to Dr. W. H. Fitton. A handsomely bound volume has recently come into my possession which puts the question beyond doubt. Dr. Fitton had evidently gathered together his various contributions to the Edinburgh Review in this volume, carefully covering over such parts of the pages which he had not written. He has had a special title page and "contents" printed, which read as under:- $(a)$ "Articles published in the Edinburgh . Review, 1817-1849, by W. H. Fitton, M.D.”; (b) Contents. 1. Report on Lunatic Asylums. Edin. Rev., vol. xxviii, No. 56. 1817, August. Article viii (pp. 431-471) ; 2. Transactions of the Geological Society, established in November, 1807. Edin. Rev., vol. xxix, No. 57. 1817, November. Article iv (pp. 70-94); 3. Smith's Geological Map of England. Edin. Rev., vol. xxix, No. 58. 1818, February. Article iii (pp. 310-337) ; 4. Larrey's Surgical Campaigns. Edin. Rev., vol. xxxi, No. 62. 1819, March. Article iii (pp. 309-324); 5. Buckland's Reliquiæ Diluvianæ. Edin. Rev., vol. xxxix, No. 77. 1823, October. Article x (pp. 196-234); 6. Lyell's Elements of Geology: Huttonian Theory of the Earth. Edin. Rev., vol. Ixix, No. 140. 1839, July. Article v (pp. 406-466); 7. The Silurian System, by R. I. Murchison. Edin. Rev., vol. Ixxiii, No. 147. 1841, April. Article i (pp. 1-41) ; 8. Statistics of Coal, by Richard Cowling Taylor. Edin. Rev., vol. xc, No. 182. 1849, October. Article vii (pp. 525-547)."

In the front of the book is written: "Frederick Chambers Fitton -from his father-October, 1858."

The MUSeums, Hull.

\title{
T. SHEPPaRD.
}

\section{HIGHGATE AMBER.}

Sir,-May I ask the courtesy of your aid to inquire whether any one can help me to obtain a specimen of Copaline, or Highgate Resin, or Highgate Amber. I specially require it for microscopic and chemical examination in connexion with a large book on Amber which I have in preparation. It is a pale yellow or brownish waxylooking substance found in small films or fragments in the London clay at Highgate Hill. It is a compound of carbon, hydrogen, and oxygen, and burns easily with a yellow flame and much smoke. I have been trying in vain for some time to obtain a specimen of it and would be most grateful to any of your readers for help.Yours, etc.,

Burgh Houge, Hampstead.

Geo. C. Williamson, A J.P. for London. 